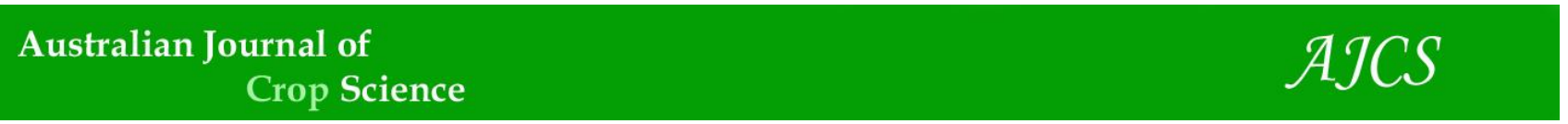

\title{
Application of biofertilizer in degraded pasture modified C dynamics and improved forage yield in a short-term period at the tropical region
}

\author{
Patrick Leal Pinheiro ${ }^{1}$, Renato Ribeiro Passos ${ }^{1}$, Anderson Lopes Peçanha ${ }^{2}$, Eduardo de Sá \\ Mendonça ${ }^{1^{*}}$
}

\author{
${ }^{1}$ Agronomy Department, Federal University of Espírito Santo, CCAE, Alegre Campus, Alegre, ES, Brazil \\ ${ }^{2}$ Biology Department, Federal University of Espírito Santo, CCENS, Alegre Campus, Alegre, ES, Brazil
}

\section{*Corresponding author: eduardo.mendonca@ufes.br}

\begin{abstract}
Recovery of degraded pastures improves the sustainability of meat and milk production systems. Humic acids (HA) and endophytic diazotrophic bacteria (EDB) are known to have bio-stimulating effects on several crops but have not been tested for the recovery of degraded pastures. The aim of the present study was to evaluate soil $\mathrm{C}$ and $\mathrm{N}$ dynamics, nutrient uptake and forage yield of Brachiaria decumbens following the foliar application of HA and EDB in a degraded pasture. A randomized block design with six replications was used. The four treatments were: HA, EDB, HA+EDB and Control. The subplots consisted of four evaluation times for soil characteristics: before treatment application (0) and 30, 60 and 120 days after treatment application (ATA). Soil total organic carbon (TOC), recalcitrant carbon $\left(C_{\text {recal }}\right)$, labile carbon $\left(C_{\text {labil }}\right)$, total nitrogen $(T N)$ and $C$ and $N$ stocks were determined in the $0-5,5-$ $10,10-20$ and $20-40 \mathrm{~cm}$ of soil layers. Forage yield and leaf nutrient contents were evaluated at 30 days ATA. The application of the HA and EDB increased the TOC, $C_{\text {labil, }}$, soil $C$ stock $(\approx 18 \%)$, forage dry matter yield (16 to $52 \%$ ) and nutrient uptake $(\approx 30 \%)$ after 30 days ATA. Our results showed that the application of HA combined with EDB may be a strategy for the recovery of degraded pastures in the tropical region.
\end{abstract}

Keywords: plant growth-promoting bacteria, humic substances, rhizodeposition, grassland, biofertilizer.

Abbreviations: HA_humic acids; EDB_endophytic diazotrophic bactéria; C_carbon; N_nitrogen; ATA_after treatment application;

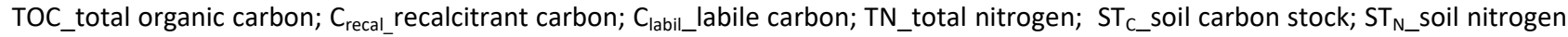
stock; SDMY_shoot dry matter yield; Ds_soil density.

\section{Introduction}

Brazil is the world's largest producer and exporter of beef (IBGE 2017), and an estimated $90 \%$ of this production is pasture fed (ANUALPEC, 2015; Pedreira et al., 2015). Pastures are the most economical way for producing and supplying food to cattle. For this reason, beef production costs in Brazil are some of the lowest in the world (Ferraz and Felício, 2010; Dias-Filho, 2014).

Despite the advantages of extensive production on pasture, low investment and the use of inadequate pasture management practices have caused the decline of forage production and the beginning of pasture degradation. Low grazing capacity, plant cover and soil fertility, and decreased soil $\mathrm{C}$ and $\mathrm{N}$ stocks characterize degraded pastures (Cerri et al., 2004; Braz et al., 2013). Fifty to $70 \%$ of the pastures in Brazil are estimated to be degraded to some degree. For this reason, the expansion of pastures into native biomes to sustain animal production has become common (Dias-Filho, 2011). To avoid this, technologies are needed to increase production and recover degraded pastures in the tropical region.

Humic acids (HA) and endophytic diazotrophic bacteria (EDB) are known to have bio-stimulating effects on the development of several crops (Canellas and Olivares, 2014;
Baldotto and Baldotto, 2014). The application of HA and EDB resulted in higher corn (Canellas et al., 2015), sugarcane (Silva et al., 2017) and Brachiaria decumbens yield (Pinheiro et al., 2018). Plant physiological changes after the application of HA and EDB have been attributed to auxingibberellin-, ethylene- and cytokinin-like activities (Canellas et al., 2015; Olivares et al., 2017). The effects of HA and EDB most often reported for plants are on the root development (Olivares et al., 2017), namely lateral root production, root hair formation and root elongation (Conceição et al., 2008; Olivares et al., 2017). These effects improve the uptake of water and nutrients by the plant. Baldotto et al. (2009) observed higher nutrient uptake following HA application during pineapple acclimation. Piedade Melo et al. (2017) showed that the application of HA and EDB alleviated water stress in common beans by increasing their root size.

Changes to roots increase the rhizosphere environment and interfere with root-soil interactions due to higher root exudation of organic acids and sugars (Puglisi et al., 2013; Nardi et al., 2017). These increases in the rhizosphere microbial community and may accelerate soil organic matter decomposition (Kuzyakov, 2010). However, the high root density of grasses may increase rhizodeposition, thereby 
maintaining organic matter in the soil (Kuzyakov, 2002). Changes to roots due to the applications of HA and EDB may therefore change soil $\mathrm{C}$ and $\mathrm{N}$ dynamics and nutrient release for plant uptake. In this context, we tested the hypothesis that HA and EDB application, in the field experiment, may increase soil $\mathrm{C}$ and $\mathrm{N}$ stocks and nutrient uptake by $B$. decumbens. The aim of the present study was to evaluate soil $\mathrm{C}$ and $\mathrm{N}$ contents and $B$. decumbens growth and nutrient uptake at different times following HA and EDB application, in a pasture with simulated grazing.

\section{Results}

The soil TOC in the $B$. decumbens pastures with HA and EDB treatments are presented in Figure 1. For the surface soil layer $(0-5 \mathrm{~cm})$, no significant interactions between treatments and evaluation times were observed, but the soil TOC slightly increased and then decreased over time. Significant interactions between treatments were observed for the deeper soil layers. For the $5-10 \mathrm{~cm}$ soil layer, at 30 days ATA, treatment application resulted in a $10 \%$ increase in the soil TOC compared to the control (Figure 1b). The opposite effect was observed for deeper soil layers, with treatment application resulting in $11.7 \%$ decrease in soil TOC relative to the control for $10-20 \mathrm{~cm}$ soil layer, and $16.9 \%$ for 20-40 cm soil layer (Figure $1 \mathrm{c}-\mathrm{d}$ ).

For the $5-10 \mathrm{~cm}$ soil layer, the opposite to that observed at 30 days ATA was obtained at 60 and 120 days ATA, with the soil TOC being, on average, $10.4 \%$ lower for the treatments than for the control. At deeper soil layers (10-20 and 20-40 $\mathrm{cm}$ ), the soil TOC increased with the HA+EDB treatment. This increase was $10.5 \%$ at 60 days ATA and $16.2 \%$ at 120 days ATA for the $10-20 \mathrm{~cm}$ soil layer, and $12.6 \%$ at 60 days ATA and $19.8 \%$ at 120 days ATA for $20-40 \mathrm{~cm}$ soil layer (Figure $1 b, c$ and d).

Soil TN differs at the $0-5$ and $20-40 \mathrm{~cm}$ soil layers (Figure $2 \mathrm{a}$ and $\mathrm{d}$ ). The HA and EDB application significantly decreased the soil TN compared to the control for both soil layers. An average decrease of $16.1,20.8$ and $26.9 \%$ was observed in the soil TN compared to the control for the surface soil layer $(p<0.05)$, and a decrease of $13.9,11.2$ and $11.3 \%$ was observed for the $20-40 \mathrm{~cm}$ soil layer $(p<0.10)$, at 30, 60 and 120 days ATA, respectively. For all soil layers, the soil TN decreased over time (Figure 2).

Soil density was $1.13,1.13$ and $1.25 \mathrm{~kg} \mathrm{dm}^{-3}$ at the $0-10,10-$ 20 and $20-40 \mathrm{~cm}$ soil layers, respectively. Soil $C\left(S_{C}\right)$ and $N$ $\left(\mathrm{ST}_{\mathrm{N}}\right)$ stocks are presented in Figure 3. The $\mathrm{ST}_{\mathrm{C}}$ and $\mathrm{ST}_{\mathrm{N}}$ were highest at the $20-40 \mathrm{~cm}$ soil layer. The application of $\mathrm{HA}+\mathrm{EDB}$ increased the $\mathrm{ST}_{\mathrm{C}}$ by 15.9 and $20.5 \%$ relative to the other treatments at the $10-20$ and $20-40 \mathrm{~cm}$ soil layers, respectively. The soil $\mathrm{ST}_{N}$ decreased with the treatment application. The application of $\mathrm{HA}$ and EDB resulted in an average decrease of 13.9 and $11 \%$ in the soil ST $_{N}$ compared to the control for the $0-5$ and $20-40 \mathrm{~cm}$ soil layers, respectively.

A significant difference in soil $C_{\text {recal }}$ between treatments was observed for all soil layers (Figure 4). At 30 days ATA, the treatments resulted in lower soil $C_{\text {recal }}$ compared to the control $(19.6,10.5,13.9$ and $28.8 \%$ for the $0-5,5-10,10-20$ and $20-40 \mathrm{~cm}$ soil layers, respectively). At 60 days ATA, a similar effect was observed for the superficial soil layers (0-5 and $5-10 \mathrm{~cm})$, there were no differences among the treatments at the $10-20 \mathrm{~cm}$ soil layer. The EDB application resulted in a decrease of $29.1 \%$ in the soil $C_{\text {recal }}$ at the $20-40$ $\mathrm{cm}$ soil layer. For all soil layers and treatments, the soil $\mathrm{C}_{\text {recal }}$ decreased at 120 days ATA.

The soil $C_{\text {labil }}$ was also significantly affected by the treatments for all soil layers (Figure 5). The treatments with $\mathrm{HA}$ and EDB induced a slight increase, followed by a decrease in $\mathrm{C}_{\text {labil }}$ for all soil layers. The EDB application increased the soil $C_{\text {labil }}$ compared to the control, for all soil layers and evaluation times $(p<0.05)$. However, $C_{\text {labil }}$ was on average 10.5 and $24.5 \%$ lower with the HA+EDB than with the EDB at the $10-20$ and $20-40 \mathrm{~cm}$ soil layers, respectively.

The shoot dry matter yield (SDMY) increased with the treatment application for all evaluation times (Figure 6). At 30 days ATA, the HA+EDB application resulted in a $52 \%$ increase in the SDMY compared to the control. The EDB and $\mathrm{HA}$ application resulted in $31 \%$ increase in the SDMY compared to the control. Similar results were obtained at 60 days ATA, with $\mathrm{HA}+\mathrm{EDB}$ resulting in an increase of $41.2 \%$ in the SDMY, and the EDB and HA showing an increase of $23.5 \%$ compared to the control. No significant differences were obtained among the treatments at 120 days ATA. The SDMY was, on average, $16 \%$ higher for the tested treatments than for the control.

The mean leaf macro and micronutrient contents 30 days after application of $\mathrm{HA}$ and $\mathrm{EDB}$ to $B$. decumbens are presented in Table 3. The $H A$ and EDB application increased the leaf $\mathrm{N}, \mathrm{P}, \mathrm{K}, \mathrm{Ca}, \mathrm{Mg}, \mathrm{Mn}, \mathrm{Cu}$ and $\mathrm{Zn}$ contents compared to the control. The $\mathrm{HA}$ and EDB application resulted in increases of 23, 29 and $80 \%$ in the N, P and Cu contents, respectively, compared to the control. The EDB application, alone or together with $\mathrm{HA}$, resulted in higher plant $\mathrm{N}, \mathrm{P}$ and $\mathrm{Cu}$ uptake. No significant differences in the leaf $\mathrm{K}, \mathrm{Mg}$ and $\mathrm{Mn}$ contents were observed between the HA and EDB treatments, but $\mathrm{HA}$ and EDB application increased the leaf $\mathrm{K}$, $\mathrm{Mg}$ and $\mathrm{Mn}$ contents $(35,23$ and 31\%, respectively) compared to the control. The leaf $\mathrm{Ca}$ contents were highest with $H A+E D B$, and the leaf $\mathrm{Zn}$ contents were highest with the HA applied alone.

\section{Discussion}

Foliar application of $\mathrm{HA}$ and EDB to $B$. decumbens changed the soil $C$ dynamics (Figures 1, 3, 4 and 5). These results were observed for all experimental period $(p<0.05)$ and were more pronounced at the $10-40 \mathrm{~cm}$ soil layer. The highest percentage of effective roots of $B$. decumbens was observed in this soil layer (Cunha et al., 2010).

Several studies have reported that HA and EDB improve the root architecture (reviewed by Olivares et al., 2017). The rhizosphere is an environment where complex rootmicroorganism-soil interactions take place, and these interactions affect the soil C dynamics (Badri et al., 2009). The increase of rhizosphere, resulted in a higher release of organic compounds by plants through excretion or root death. These compounds increase the activity of the microorganisms involved in the $\mathrm{C}$ cycle, especially in the soil organic matter formation and decomposition (Kuzyakov, 2010; Nardi et al., 2017). Our study shows changes in the soil TOC (Figure 1c-d), $C_{\text {recal }}$ (Figure $4 c-d$ ) and $C_{\text {labil }}$ (Figure $5 c-d$ ) contents 30 days ATA at the $10-40 \mathrm{~cm}$ soil layer. These changes may be related to the use of the soil $C$ for microbial growth in the rhizosphere or in "hot spots" close to the roots. In addition, the compounds released by plants and higher microbial activity may have changed the soil $C$ and promoted the transformation of $\mathrm{C}_{\text {recal }}$ into $\mathrm{C}_{\text {labil }}$. Organo- 
Table 1. Soil physical and chemical characterization of the $0-20$ and $20-40 \mathrm{~cm}$ soil layers.

\begin{tabular}{lll}
\hline \multirow{2}{*}{ Soil characteristics } & \multicolumn{2}{c}{ Depth } \\
\cline { 2 - 3 } & $0-20 \mathrm{~cm}$ & $20-40 \mathrm{~cm}$ \\
\hline Chemical analysis & & \\
\hline $\mathrm{pH}\left(\mathrm{H}_{2} \mathrm{O}\right)$ & 5.4 & 6.0 \\
$\left.\mathrm{P}(\mathrm{mg} \mathrm{dm})^{-3}\right)$ & 8.6 & 1.6 \\
$\left.\mathrm{~K}(\mathrm{mg} \mathrm{dm})^{-3}\right)$ & 171.5 & 49.5 \\
$\mathrm{Na}\left(\mathrm{mg} \mathrm{dm}^{-3}\right)$ & 1.6 & 0.6 \\
$\mathrm{Ca}^{2+}\left(\mathrm{cmol}_{\mathrm{c}} \mathrm{dm}^{-3}\right)$ & 1.6 & 1.0 \\
$\mathrm{Mg}^{2+}\left(\mathrm{cmol}_{\mathrm{c}} \mathrm{dm}^{-3}\right)$ & 1.0 & 0.6 \\
$\mathrm{Al}^{3+}\left(\mathrm{cmol}_{\mathrm{c}} \mathrm{dm}^{-3}\right)$ & 0.1 & 0 \\
$\mathrm{H}+\mathrm{Al}\left(\mathrm{cmol}_{\mathrm{c}} \mathrm{dm}^{-3}\right)$ & 4.1 & 2.9 \\
$\mathrm{SB}\left(\mathrm{cmol}_{\mathrm{c}} \mathrm{dm}^{-3}\right)$ & 3.1 & 1.7 \\
$\mathrm{t}\left(\mathrm{cmol}_{\mathrm{c}} \mathrm{dm}^{-3}\right)$ & 3.1 & 1.7 \\
$\left.\mathrm{~T}\left(\mathrm{cmol}_{\mathrm{c} \mathrm{dm}}\right)^{-3}\right)$ & 7.1 & 4.6 \\
$\mathrm{~S}(\%)$ & 43.0 & 37.4 \\
$\mathrm{~m}(\%)$ & 1.9 & 0 \\
$\mathrm{Granulometric}$ analysis & & \\
Sand $\left(\mathrm{g} \mathrm{kg}^{-1}\right)$ & 498.6 & 508.2 \\
Silt $\left(\mathrm{g} \mathrm{kg}^{-1}\right)$ & 104.8 & 98.5 \\
Clay $\left(\mathrm{g} \mathrm{kg}^{-1}\right)$ & 396.6 & 393.4 \\
\hline
\end{tabular}

pH: active acidity; P: phosphorus; K: potassium; Na: sodium; Ca: calcium; Mg: magnesium; Al: aluminium; H + Al: potential acidity; SB: sum of bases; t: effective cation exchange capacity; T: total cation exchange capacity; $\mathrm{S}$ : saturation of bases; $\mathrm{m}$ : aluminium saturation.

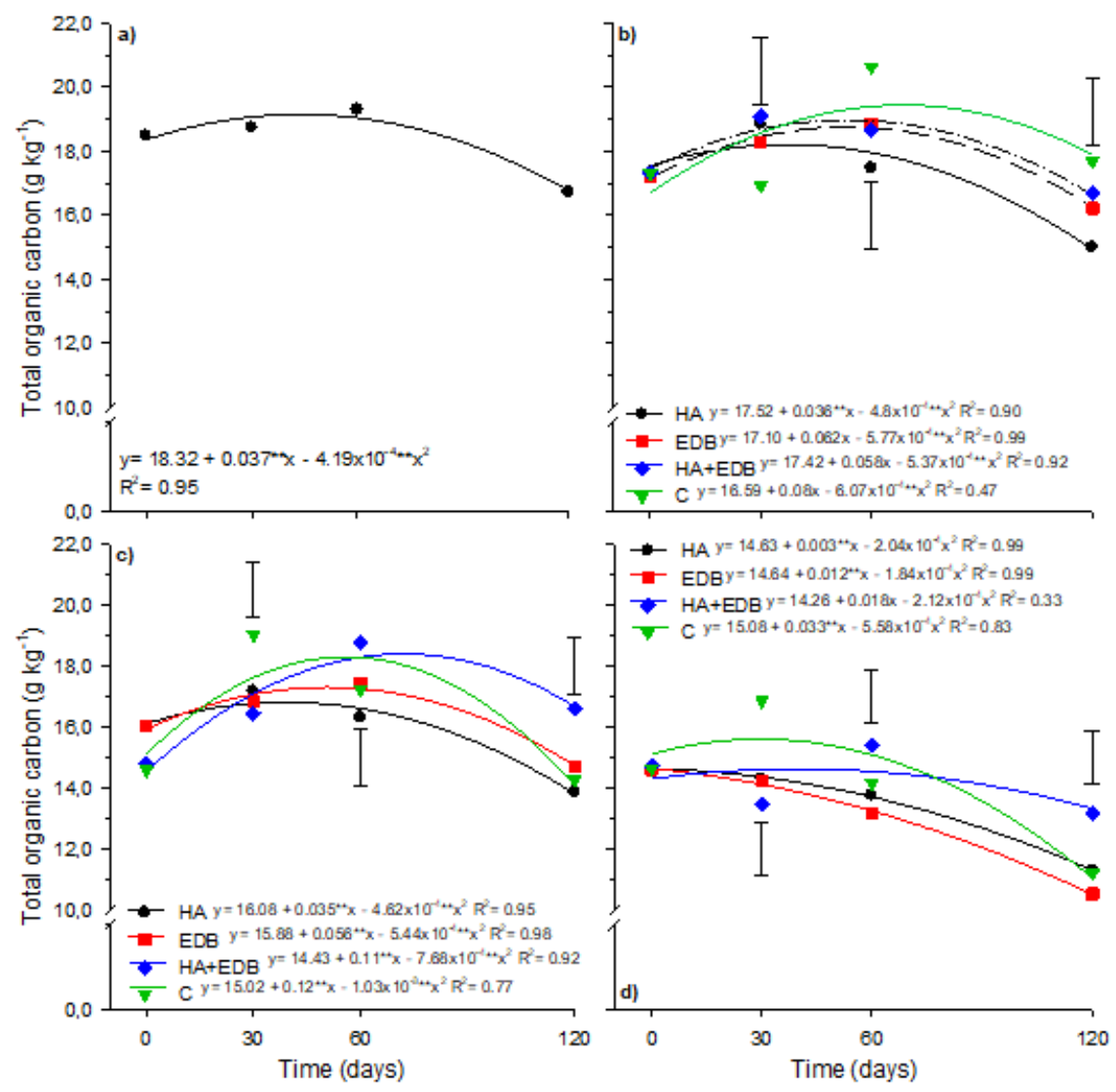

Fig 1. Soil total organic carbon concentrations for the 0-5 (a), 5-10 (b), 10-20 (c) and 20-40 cm (d) soil layers at different times after treatment application. HA: Humic acids; EDB: Endophytic diazotrophic bacteria; HA+EDB: Humic acids and endophytic diazotrophic bacteria; C: Control. ${ }^{* *}$ significant according to the t-test $(p \leq 0.01)$. Vertical bars indicate the least significant difference (LSD, $p \leq 0.05)$ between treatments for each evaluation time.

Table 2. Mean composition of the vermicompost used to extract humic acids.

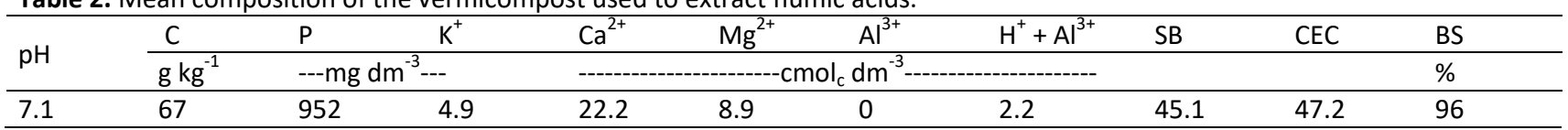




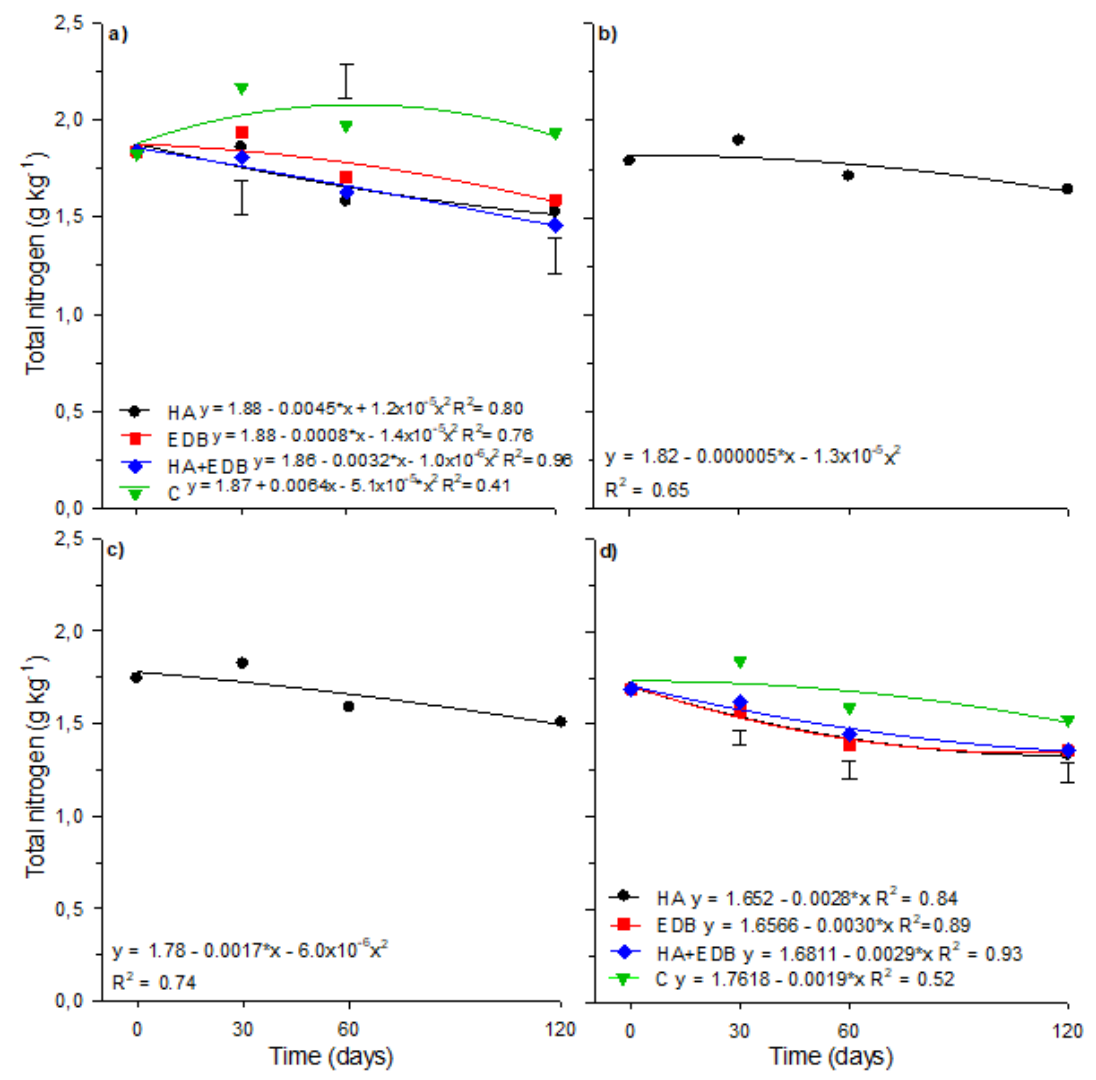

Fig 2. Soil total nitrogen concentrations for the 0-5 (a), 5-10 (b), 10-20 (c) and 20-40 cm (d) soil layers at different times after treatment application. HA: Humic acids; EDB: Endophytic diazotrophic bacteria; HA+EDB: Humic acids and endophytic diazotrophic bacteria; C: Control. * significant according to the t-test ( $p \leq 0.05)$. Vertical bars indicate the least significant difference (LSD, $p \leq 0.05)$ between treatments for each evaluation time.

Table 3. Nutrient contents of Brachiaria decumbens 30 days after the application of the humic acids and endophytic diazotrophic bacteria.

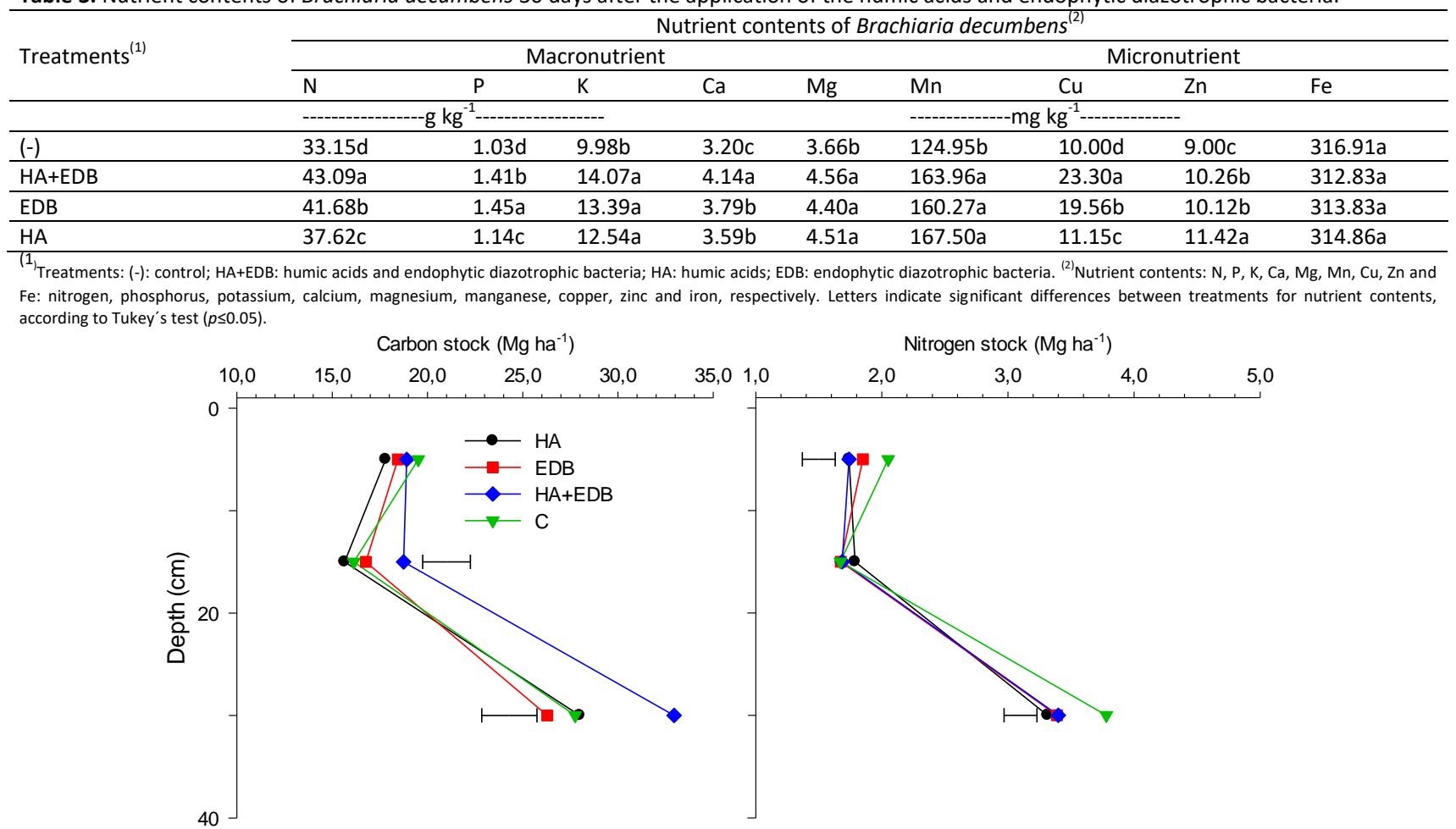

Fig 3. Carbon and nitrogen stocks 120 days after treatment application for the $0-10,10-20$ and $20-40 \mathrm{~cm}$ soil layers. HA: humic acids; EDB: endophytic diazotrophic bacteria; HA+EDB: Humic acids and endophytic diazotrophic bacteria; C: control. Horizontal bars indicate the least significant difference (LSD, $p \leq 0.05$ ) between treatments. 


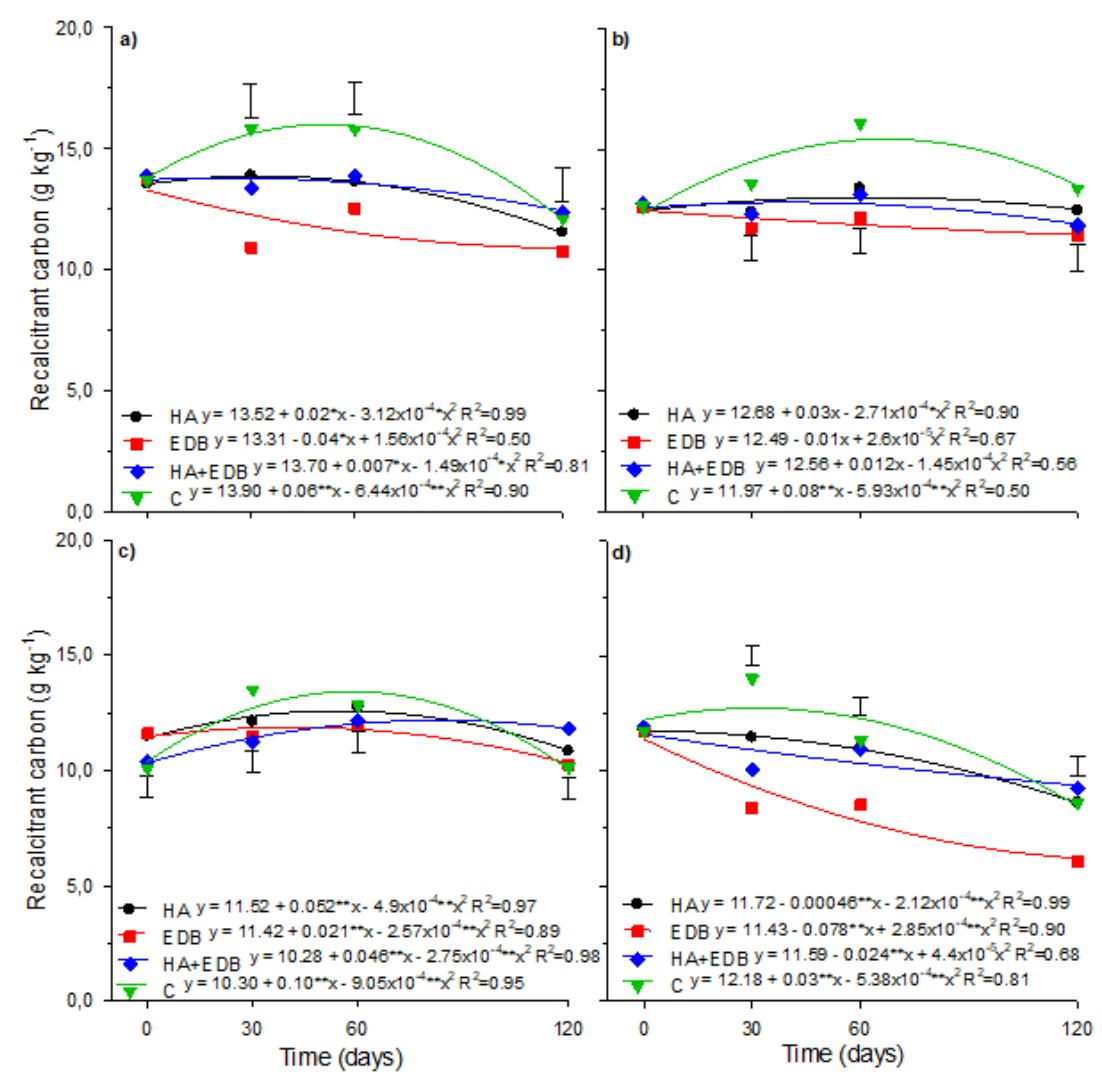

Fig 4. Soil recalcitrant organic carbon in the 0-5 (a), 5-10 (b), 10-20 (c) and 20-40 cm (d) soil layers at different times after treatment application. HA: Humic acids; EDB: Endophytic diazotrophic bacteria; HA+EDB: Humic acids and endophytic diazotrophic bacteria; C: Control. ${ }^{* *}$ and ${ }^{*}$ significant according to the t-test $(p \leq 0.01$ and $p \leq 0.05)$. Vertical bars indicate the least significant difference (LSD, $p \leq 0.05)$ between treatments for each evaluation time.

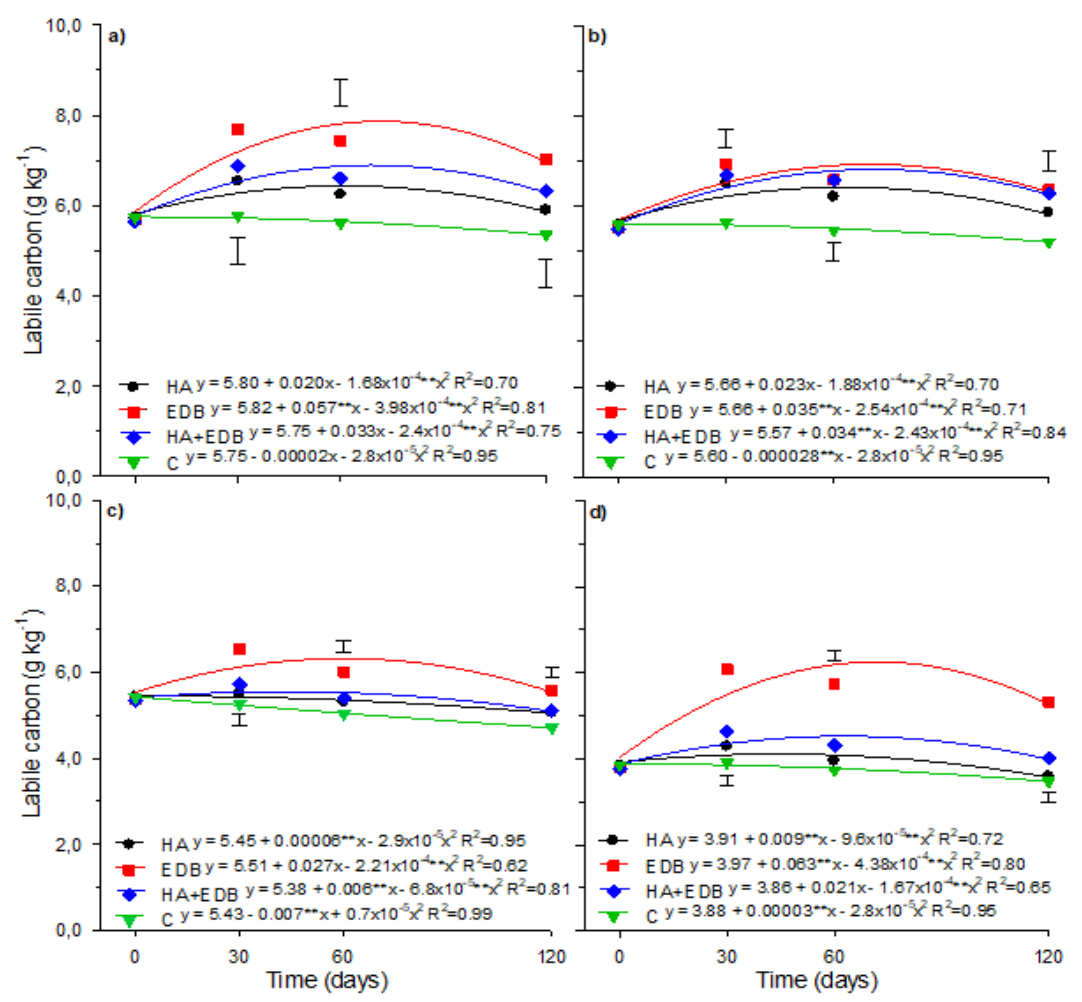

Fig 5. Soil labile organic carbon concentrations for the 0-5 (a), 5-10 (b), 10-20 (c) and 20-40 cm (d) soil layers at different times after treatment application. HA: Humic acids; EDB: Endophytic diazotrophic bacteria; HA+EDB: Humic acids and endophytic diazotrophic bacteria; C: Control. ${ }^{* *}$ significant according to the t-test $(p \leq 0.01)$. Vertical bars indicate the least significant difference (LSD, $p \leq 0.05$ ) between treatments for each evaluation time. 


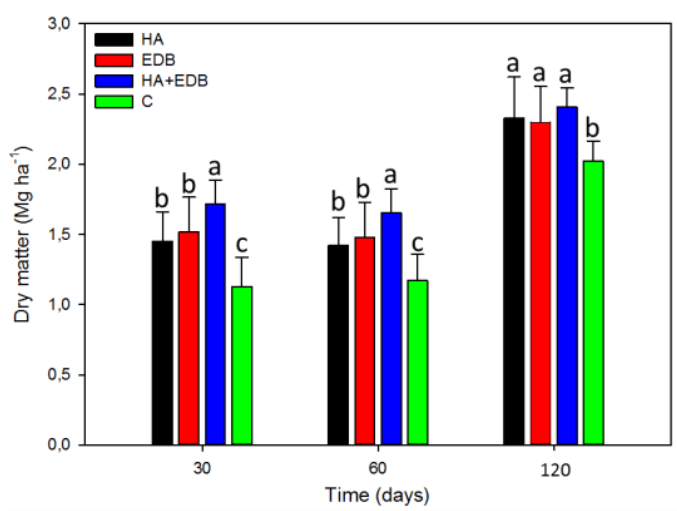

Fig 6. Brachiaria decumbens shoot dry matter yield for the different treatments at different times after treatment application. $\mathrm{HA}$ : Humic acids; EDB: Endophytic diazotrophic bacteria; HA+EDB: Humic acids and endophytic diazotrophic bacteria; C: Control. Vertical bars indicate the standard deviation. For each evaluation time, treatment means followed by different upper-case letters are significantly different according to Tukey's test $(p \leq 0.05)$.

mineral associations are important mechanisms for soil $\mathrm{C}$ protection (Six et al., 2002). However, Keiluweit et al. (2015) showed that root exudates might release $C$ from these organo-mineral associations, making the $C$ readily available. The establishment of $B$. decumbens resulted in changes to the soil $C$ dynamics at 30 days ATA. At 60 days ATA, the soil TOC was higher for treatment HA+EDB (Figure 1c-d). A slight increase in soil $C_{\text {recal }}$ (Figure $4 c-d$ ) and a decrease in soil $C_{\text {labil }}$ (Figure 5c-d) were observed. According to our hypothesis, the increase in the soil TOC was due to an increase in the roots and the slow decomposition of dead roots. As the $C$ derived from dead roots has low lability, microorganisms become more efficient at decomposing the soil organic matter (Kuzyakov, 2010). Labile organic compounds in soil organic matter and root exudates are easily decomposed and become substrates for microbial growth (Bais et al., 2006; Kuzyakov, 2010; Philippot et al., 2013). This C dynamic explains the inversion of the soil $C_{\text {recal }}$ and $C_{\text {labil }}$ contents observed in the present study.

The response of the soil TOC to the application of EDB alone should be highlighted (Figure 1c-d). This treatment presented lower soil TOC but higher soil $C_{\text {labil }}$ (Figure $5 c-d$ ) than the other treatments $(p<0.05)$. The increase in microbial activity in this treatment promoted the transformation of recalcitrant $C$ into labile C. The EDB treatments generated an increase in the $C$ content of the soil microbial biomass (data not shown). Furthermore, root exudates may increase the microbial activity in the rhizosphere, increasing the soil organic matter decomposition (Haichar et al., 2014).

Adequate pasture management may increase the soil $\mathrm{ST}_{\mathrm{C}}$ (Braz et al., 2013). In our study, the HA+EDB application resulted in an increase in the $\mathrm{ST}_{\mathrm{C}}$ in the soil layer where the grass effective roots are located (Figure 3 ). This treatment may have increased root mass in the soil layer, changing the $C$ dynamics and increasing the soil $C$ contents. In addition, the roots of Brachiaria species have a great potential to accumulate belowground C (Batlle-Bayer et al., 2010).

Soil $N$ dynamics were different from the soil $C$ dynamics. The $\mathrm{HA}$ and EDB application decreased the soil TN and $\mathrm{ST}_{\mathrm{N}}$. As previously discussed, the HA and EDB change the root architecture and may increase root exudation. Increased root exudation leads to higher $\mathrm{N}$ demand for microbial growth (Zhu et al., 2014). Soil organic matter decomposition and $\mathrm{N}$ mineralization in the rhizosphere may increase in order to meet this increase in $\mathrm{N}$ demand (Koranda et al., 2011; Meier et al., 2017), resulting in higher amounts of soil $\mathrm{N}$ becoming available to plants due to the prompt turnover of microbial biomass (Kuzyakov and Xu, 2013; Zhu et al., 2014). The low soil TN obtained after the HA and EDB application may therefore be related to the plant $\mathrm{N}$ uptake following soil organic matter decomposition by microorganisms. The use of HA and EDB together with adequate pasture management may therefore be an effective strategy to increase system sustainability.

The potential of HA and EDB application to increase $B$. decumbens forage yield was observed in the present study. The bio-stimulating effects of HA and EDB are related to their plant hormone-like effects and are responsible for plant growth and development (Canellas et al., 2015; Olivares et al., 2017). Notably, a synergistic effect between $\mathrm{HA}$ and EDB was observed in the present study, indicated by the higher SDMY observed for the HA+EDB treatment (Figure 6).

The application of HA and EDB increased plant uptake of all nutrients, except Fe. (Table 3 ). The main effects of HA and EDB are morpho-anatomical changes to root architecture, increasing lateral root and root hair formation (Canellas et al., 2015). In addition, HA and EDB also affect the root biochemistry, increasing the synthesis of plasma membrane $\mathrm{H}+$-ATPases. This increase improves energy production for the secondary ion transport system and promotes root water and nutrient uptake (Canellas and Olivares, 2014; Lima et al., 2014).

In addition, the Herbaspirillum strains used in the present study are $\mathrm{N}$-fixing and $\mathrm{P}$-solubilizing (Olivares et al., 2017). Higher $\mathrm{N}$ and $\mathrm{P}$ contents were therefore observed with EDB application. The higher root growth and exudation may have promoted root colonization by Herbaspirillum. This enabled higher fixation of atmospheric $\mathrm{N}$ and solubilization of soil $\mathrm{P}$ compounds, resulting in higher root nutrient uptake. Similar effects were observed for the uptake of $\mathrm{N}$ (Canellas et al., 2013) and $P$ in corn (Giro et al., 2016).

\section{Materials and Methods}

The study was carried out in a degraded pasture of palisade grass (Brachiaria decumbens Stapf cv. Basilisk) located in a farm in Alegre municipality, state of Espirito Santo, Brazil ( $20^{\circ} 45^{\prime} 49^{\prime \prime} \mathrm{S}, 41^{\circ} 31^{\prime} 57^{\prime \prime} \mathrm{W}$; approximately $200 \mathrm{~m}$ altitude). 
The region's climate is type Cfa according to the Köppen climate classification (Alvares et al., 2013), with hot and rainy summers and dry winters, $22^{\circ} \mathrm{C}$ mean annual temperature and $1200 \mathrm{~mm}$ mean annual rainfall. The soil has been classified as Typic Haplustox (Soil Survey Staff, 2010). The soil's physical and chemical characteristics are presented in Table 1.

The pasture was renewed 6 months before the beginning of the experiment. Liming and fertilization were performed based on the soil chemical analysis and crop requirements (Prezotti et al., 2007). One month before the beginning of the experiment, an area of $333 \mathrm{~m}^{2}$ (37 m length and $9 \mathrm{~m}$ width) was selected, delimited and fenced. Twenty-four experimental units of $6 \mathrm{~m}^{2}$, with a border of $1 \mathrm{~m}$, were delimited within this area. Before the treatment application, the pasture was mowed using a mechanical mower to $10 \mathrm{~cm}$ above the ground to simulate grazing.

The experiment design adopted was randomized blocks with six replications and four treatments: $\mathrm{HA}\left(20 \mathrm{mg} \mathrm{C} \mathrm{L}^{-1}\right)$ applied at $450 \mathrm{~L} \mathrm{ha}^{-1}$, EDB (EDB mix containing $10^{9}$ viable cells $\mathrm{L}^{-1}$ ) applied at $350 \mathrm{~L} \mathrm{ha} \mathrm{a}^{-1}$, combined use of $\mathrm{HA}+\mathrm{EDB}$, and the control (C). Soil characteristics were evaluated at four times: before treatments application (0) and 30, 60 and 120 days after the treatment application (ATA). The treatments were applied to the leaves with a 20-L manual backpack sprayer (JACTO-PJH2O), with the doses being adjusted to the experimental units.

The HAs were extracted from a vermicompost produced from pen manure and sugarcane filter cake $(5: 1, v / v)$ at the Centre for the Development of Biological Inputs for Agriculture (NUDIBA), Universidade Estadual do Norte Fluminense (State University of Northern Rio de Janeiro; UENF), Goytacazes Campus, state of Rio de Janeiro. The organic residues were mixed, and worms (Eisenia foetida) were added at a ratio of $5 \mathrm{~kg}$ of worms per $\mathrm{m}^{3}$ of organic residue. The vermicompost was air dried, sieved $(2 \mathrm{~mm})$ and chemically characterized (Table 2).

For HAs extraction, vermicompost was added to $0.5 \mathrm{~mol} \mathrm{~L}^{-1}$ $\mathrm{KOH}(1: 10, \mathrm{v}: \mathrm{v})$, stirred for $6 \mathrm{~h}$ and left to stand for $12 \mathrm{~h}$. The supernatant was collected, acidified to $\mathrm{pH} 1.5$ with $1 \mathrm{~mol} \mathrm{~L}^{-1}$ $\mathrm{H}_{2} \mathrm{SO}_{4}$ then extracted and discarded. The decanted material was centrifuged ( $2657 \mathrm{~g}, 20 \mathrm{~min}$ ), and the supernatant was discarded. The HAs were titrated to $\mathrm{pH} 7.0$ with $0.1 \mathrm{~mol} \mathrm{~L}^{-1}$ $\mathrm{KOH}$, placed in petri dishes, added to an oven at $45^{\circ} \mathrm{C}$ until constant weight was achieved. The $\mathrm{C}$ concentration of the HAs samples was quantified through wet oxidation of organic matter (Yeomans and Bremner, 1988).

A strain of Herbaspirillum rubrisubalbicans (HCC 101) and two strains of Herbaspirillum seropedicae (HIV 206, HIII 215) were used. The bacterial strains used have been deposited in the culture collection of the Laboratory of Cell and Tissue Biology of the Universidade Estadual do Norte Fluminense Darcy Ribeiro (State University of Northern Rio de Janeiro Darcy Ribeiro; LBCT/UENF). The inoculum was grown in DYGS liquid medium at $120 \mathrm{rpm}$ and $30^{\circ} \mathrm{C}$ for $24 \mathrm{~h}$, and the bacterial suspension was adjusted to $10^{9}$ cells per $\mathrm{mL}$ (Döbereiner et al., 1995).

For each experimental unit, three disturbed soil samples were collected from four soil layers (0-5, 5-10, 10-20 and 20$40 \mathrm{~cm}$, with a Dutch auger) and combined to form a composite sample. The disturbed soil samples were air dried and sieved (2-mm diameter) to remove root pieces and stones. An undisturbed soil sample was also collected (0-10, $10-20$ and $20-40 \mathrm{~cm}$ ) for determination of soil density, using the volumetric ring method.
Soil samples ( $20 \mathrm{~g})$ were ground and sieved $(250 \mu \mathrm{m})$. The soil total organic carbon (TOC), total nitrogen (TN), labile C $\left(C_{\text {labil }}\right)$ and recalcitrant $C\left(C_{\text {recal }}\right)$ concentrations were determined for the $0-5,5-10,10-20$ and $20-40 \mathrm{~cm}$ soil layers. The TOC was quantified through wet oxidation of the organic matter (Yeomans and Bremner, 1988). The TN was quantified by sulphuric acid digestion (Bremmer and Mulvaney, 1982; Tedesco et al., 1995). Soil organic C fractions were determined according to Chan et al. (2001). Fraction 1 (very labile), C oxidized in acid medium $\left(3 \mathrm{~mol} \mathrm{~L}^{-1}\right.$ $\mathrm{H}_{2} \mathrm{SO}_{4}$ ); Fraction 2 (labile), calculated as the difference between $\mathrm{C}$ oxidized in 6 and $3 \mathrm{~mol} \mathrm{~L}^{-1} \mathrm{H}_{2} \mathrm{SO}_{4}$; Fraction 3 (less labile), calculated as the difference between $\mathrm{C}$ oxidized in 9 and $6 \mathrm{~mol} \mathrm{~L}^{-1} \mathrm{H}_{2} \mathrm{SO}_{4}$; and Fraction 4 (non-labile), calculated as the difference between the TOC and Coxidized in $9 \mathrm{~mol} \mathrm{~L}$ ${ }^{1} \mathrm{H}_{2} \mathrm{SO}_{4}$. The sum of fractions 1 and 2 correspond to $\mathrm{C}_{\text {labil; }}$ the sum of fractions 3 and 4, to $C_{\text {recal }}$ (Chan et al., 2001).

Soil density (Ds) was determined and used to calculate soil $C$ $\left(\mathrm{ST}_{\mathrm{C}}\right)$ and $\mathrm{N}\left(\mathrm{ST}_{\mathrm{N}}\right)$ stocks $\left(\mathrm{Mg} \mathrm{ha}{ }^{-1}\right)$ for each soil layer according to $S T C=T O C X D s x e$ and $S T n=T N x D s x e$, where: STc,n are expressed in $\mathrm{Mg} \mathrm{ha}^{-1}$, TOC and TN are expressed in $\mathrm{g} \mathrm{kg}^{-1}, \mathrm{Ds}$ in $\mathrm{kg} \mathrm{dm}^{-3}$, and $e$ (soil layer thickness) in $\mathrm{cm}$.

Shoot dry matter was determined 30, 60 and 120 days after treatment application. Three samples were collected randomly from each experimental unit, using a quadrant with $0.09 \mathrm{~m}^{2}(0.3 \times 0.3 \mathrm{~m})$. The grass was cut to $10 \mathrm{~cm}$ aboveground to simulate grazing. The samples were oven dried at 65 o $C$ for $72 \mathrm{~h}$, and used to determine the dry weight and the dry matter yield. Macro- ( $N, P, K, C a$ and $\mathrm{Mg}$ ) and micronutrient ( $\mathrm{Zn}$. Cu. $\mathrm{Mn}$ and $\mathrm{Fe}$ ) concentrations were also measured. Leaf $\mathrm{N}$ content was determined by sulphuric acid digestion followed by Kjeldahl distillation. Leaf $\mathrm{P}, \mathrm{K}, \mathrm{Ca}, \mathrm{Mg}$, $\mathrm{Zn}, \mathrm{Cu}, \mathrm{Mn}$ and Fe contents were determined following nitric perchloric acid digestion according to Johnson and Ulrich (1959) and Malavolta and Moreira (1997).

\section{Statistical analysis}

The data were submitted to analysis of variance (ANOVA) and means between treatments were compared using the least significant difference of a Tukey test $(p \leq 0.05)$. When significant differences were found, applied regression analysis was performed for the evaluation times. Models were chosen based on the significance of the regression coefficients, according to Student t-test ( $p \leq 0.05$ and $p \leq 0.01$ ) and according to the coefficient of determination $\left(R^{2}\right)$. Statistical analyses were carried out with $R$ program ( $R$ Core Team 2018).

\section{Conclusions}

The observed increase in forage production and the increase in soil $\mathrm{ST}_{\mathrm{C}}$ showed the viability of $\mathrm{HA}$ and EDB application for the recovery of degraded pastures. Although $\mathrm{N}$-fixing EDB were used in the present study, a decrease was observed in the soil $\mathrm{ST}_{\mathrm{N}}$. However, no $\mathrm{N}$ fertilization was applied, and animals were not allowed in the area during the experimental period. Thus, only $\mathrm{N}$ export from the system took place. Therefore, further studies of the use of this biotechnology, together with adequate pasture management, are needed. The most important factor in degraded pasture recovery is avoidance of the expansion of low production systems into native biomes. The present study may therefore result in strategies that help recover 
degraded pastures, enabling the preservation of fragile ecosystems.

\section{Acknowledgements}

The authors wish to thank the Brazilian government through Fundação de Amparo à Pesquisa e Inovação do Espírito Santo (FAPES) and the Conselho Nacional de Desenvolvimento Científico e Tecnológico (CNPq) for the financial support, and professors Luciano Pasqualoto Canellas and Fábio Lopes Olivares from the Universidade Estadual do Norte Fluminense Darcy Ribeiro (LBCT/UENF), for supplying the bacterial strains and vermicompost used in the study.

\section{Conflicts of Interest}

The authors declare no conflicts of interest.

\section{References}

Alvares CA, Stape JL, Sentelhas PC, de Moraes Gonçalves JL, Sparovek G (2013) Köppen's climate classification map for Brazil. Meteo Zeits. 22:711-728.

ANUALPEC/FNP. (2015) Anuário da Pecuária Brasileira (Yearbook of Brazilian Livestock). São Paulo(SP): Instituto FNP, AGRA FNP Pesquisas Ltda.

Badri DV, Weir TL, van der Lelie D, Vivanco JM (2009) Rhizosphere chemical dialogues: plant-microbe interactions. Cur Opin Biotech. 20:642-650.

Bais HP, Weir TL, Perry LG, Gilroy S, Vivanco JM (2006) The role of root exudates in rhizosphere interactions with plants and other organisms. Ann Rev Plant Biol. 57:233266.

Baldotto LEB, Baldotto MA, Giro VB, Canellas LP, Olivares FL, Bressan-Smith R (2009) Desempenho do abacaxizeiro 'Vitória' em resposta à aplicação de ácidos húmicos durante a aclimatação. Rev Bras Ci Solo. 33:979-990.

Batlle-Bayer L., Batjes N. H., Bindraban P. S. (2010). Changes in organic carbon stocks upon land use conversion in the Brazilian Cerrado: A review. Agric Ecos Envi. 137:47-58.

Braz SP, Urquiaga S, Alves BJR, Jantalia CP, Guimarães AP, dos Santos CA, dos Santos SC, Machado Pinheiro EF, Boddey RM (2013) Soil carbon stocks under productive and degraded pastures in the Brazilian Cerrado. Soil Sci Soc Am J. 77:914.

Bremner JM, Mulvaney CS (1982) Nitrogen-Total. In: Methods of soil analysis. Part 2. Chemical and microbiological properties, Page AL, Miller RH, Keeney DR. Eds., American Society of Agronomy. Soil Sci Soc Am. Madison, Wisconsin. p. 595-624.

Canellas LP, Balmori DM, Médici LO, Aguiar NO, Campostrini E, Rosa RCC, Façanha AR, Olivares FL (2013) A combination of humic substances and Herbaspirillum seropedicae inoculation enhances the growth of maize (Zea mays L.). Plant Soil. 366:119-132.

Canellas LP, Olivares FL (2014) Physiological responses to humic substances as plant growth promoter. Chem Biol Tech Agri. 1, 3.

Canellas LP, Olivares FL, Aguiar NO, Jones DL, Nebbioso A, Mazzei P, Piccolo A (2015) Humic and fulvic acids as biostimulants in horticulture. Sci Hort. 196:15-27.

Cerri CEP, Bernoux M, Chaplot V, Volkoff B, Victoria, RL, Melillo JM, Paustian K, Cerri CC (2004) Assessment of soil property spatial variation in an Amazon pasture: Basis for selecting an agronomic experimental area. Geoderma. 123:51-68.

Chan KY, Bowman A, Oats A (2001) Oxidizable organic carbon fractions and soil quality changes in an Oxic Paleustalf under different pasture leys. Soil Sci. 166:61-67. Conceição PM, Vieira HD, Canellas LP, Marques Júnior RB, Olivares FL (2008) Recobrimento de sementes de milho com ácidos húmicos e bactérias diazotróficas endofíticas. Pesq Agro Bras. 43:545-548.

Cunha FF, Ramos MM, Alencar CAB, Martins CE, Cóser AC, Oliveira, RA (2010) Sistema radicular de seis gramíneas irrigadas em diferentes adubações nitrogenadas e manejos. Acta Scien Agro. 32:351-357.

Dias-Filho MB (2011) Os desafios da produção animal em pastagens na fronteira agrícola brasileira. Rev Bras Zootec. 40:243-252.

Dias-Filho MB (2014) Diagnóstico das Pastagens no Brasil. Belém (PA): Embrapa Amazônia Ambiental.

Döbereiner J, Baldani VLD, Baldani JI (1995) Como isolar e identificar bactérias diazotróficas de plantas nãoleguminosas. Brasília: Embrapa-SPI.

Ferraz JBS, Felício PE (2010) Production systems - An example from Brazil. Meat Sci. 84:238-243.

Giro VB, Jindo K, Vittorazzi C, Oliveira RS, Conceição GP, Canellas LP, Olivares FL (2016) Rock phosphate combined with phosphate-solubilizing microorganisms and humic substance for reduction of plant phosphorus demands from single superphosphate. Acta Hort. 1146:63-68.

Haichar FZ, Santaella C, Heulin T, Achouak W (2014) Root exudates mediated interactions belowground. Soil Biol Biochem. 77:69-80.

IBGE. (2017). Estatística da Produção Pecuária. Rio de Janeiro (RJ): IBGE. p. 1-47.

Johnson CM, Ulrich A (1959) Analytical methods for use in plants analyses. Los Angeles (LA): University California. Bulletin. 766:32-33.

Keiluweit M, Bougoure JJ, Nico PS, Pett-Ridge J, Weber PK, Kleber M (2015) Mineral protection of soil carbon counteracted by root exudates. Nature Cli Change. 5:588595.

Koranda M, Schnecker J, Kaiser C, Fuchslueger L, Kitzler B, Stange, CF, Sessitsch, A, Zechmeister-Boltenstern, S, Richter, A (2011) Microbial processes and community composition in the rhizosphere of European beech - The influence of plant $C$ exudates. Soil Biol Biochem. 43:551558.

Kuzyakov Y (2002) Review: Factors affecting rhizosphere priming effects. J Plant Nut Soil Sci. 165:382-396.

Kuzyakov Y (2010) Priming effects: Interactions between living and dead organic matter. Soil Biol Biochem. 42:1363-1371.

Kuzyakov Y, Xu X (2013) Competition between roots and microorganisms for nitrogen: Mechan ecolog relev. New Phytol. 198:656-669.

Lima LS, Olivares FL, Rodrigues OR, Vega MR G, Aguiar NO, Canellas LP (2014) Root exudate profiling of maize seedlings inoculated with Herbaspirillum seropedicae and humic acids. Chem Biol Tech Agri. 1:23.

Malavolta E, Moreira A (1997) Nutrição e adubação do cafeeiro adensado. Piracicaba: Informações Agronômicas. 80:1-7. (Encarte técnico).

Meier IC, Finzi AC, Phillips RP (2017) Root exudates increase $\mathrm{N}$ availability by stimulating microbial turnover of fastcycling N pools. Soil Biol Biochem. 106:119-128. 
Nardi S, Ertani A, Francioso O (2017) Soil-root cross-talking: The role of humic substances. J Plant Nut Soil Sci. 180:513.

Olivares FL, Busato JG, De Paula AML, Lima S, Oliveira AN, Canellas LP (2017) Plant growth promoting bacteria and humic substances: crop promotion and mechanisms of action. Chem Biol Tech Agri. 4:1-13.

Pedreira CGS, Silva LS, Alonso MP (2015) Use of grazed pastures in the brazilian livestock industry: a brief overview. Forages in Warm Climates 7.

Philippot L, Raaijmakers JM, Lemanceau P, Van Der Putten WH (2013) Going back to the roots: The microbial ecology of the rhizosphere. Nature Rev Microb. 11:789-799.

Piedade MA, Olivares FL, Médici LO, Torres-Neto A, Dobbss LB, Canellas LP (2017) Mixed rhizobia and Herbaspirillum seropedicae inoculations with humic acid-like substances improve water-stress recovery in common beans. Chemical and Biological Technologies in Agriculture. 4:6.

Prezotti LC, Gomes JA, Dadalto GG, Oliveira JA (2007) Manual de Recomendação de Calagem e Adubação para o Estado do Espírito Santo - 5a aproximação. Vitória: SEEA/INCAPER/CEDAGRO.

Puglisi E, Pascazio S, Suciu N, Cattani I, Fait G, Spaccini R,
Crecchio C, Piccolo A, Trevisan M (2013) Rhizosphere microbial diversity as influenced by humic substance amendments and chemical composition of rhizodeposits. J Geochem Explo. 129:82-94.

Six J, Conant RT, Paul EA, Paustian K (2002) Stabilization mechanisms of soil organic matter: Implications for Csaturation of soils. Plant Soil. 241:155-176.

Soil Survey Staff (2010) Keys to soil taxonomy. Unite States Department of Agriculture-Natural Resources Conservation Service, Washington, DC.

Tedesco MJ, Gianello C, Bissani CA, Bohnen H, Volkweiss SJ (1995) Análise de solo, plantas e outros materiais (second ed.). Porto Alegre (POA): Universidade Federal do Rio Grande do Sul.

Yeomans JC, Bremner JM (1988) A rapid and precise method for routine determination of organic carbon in soil. Communications in Soil Sci Plant Anal. 19:1467-1476.

Zhu B, Gutknecht JLM, Herman DJ, Keck DC, Firestone MK, Cheng W (2014) Rhizosphere priming effects on soil carbon and nitrogen mineralization. Soil Biol Biochem. 76:183-192. 